\title{
Mast cell: an emerging partner in immune interaction
}

\section{Giorgia Gri, Barbara Frossi, Federica D'Inca, Luca Danelli, Elena Betto, Francesca Mion, Riccardo Sibilano and Carlo Pucillo*}

Immunology Laboratory, Department of Medical and Biological Science, University of Udine, Udine, Italy

\author{
Edited by: \\ Ulrich Blank, Université Paris-Diderot \\ Paris 7, France \\ Reviewed by: \\ Salah Mécheri, Institut Pasteur, \\ France \\ Joana Vitte, Aix-Marseille University, \\ France \\ *Correspondence: \\ Carlo Pucillo, Immunology Laboratory, \\ Department of Medical and Biological \\ Science, University of Udine, P.le \\ Massimiliano Kolbe, 4-33100 Udine, \\ Italy. \\ e-mail: carlo.pucillo@uniud.it
}

Mast cells (MCs) are currently recognized as effector cells in many settings of the immune response, including host defense, immune regulation, allergy, chronic inflammation, and autoimmune diseases. MC pleiotropic functions reflect their ability to secrete a wide spectrum of preformed or newly synthesized biologically active products with pro-inflammatory, anti-inflammatory and/or immunosuppressive properties, in response to multiple signals. Moreover, the modulation of $\mathrm{MC}$ effector phenotypes relies on the interaction of a wide variety of membrane molecules involved in cell-cell or cell-extracellular-matrix interaction. The delivery of co-stimulatory signals allows $\mathrm{MC}$ to specifically communicate with immune cells belonging to both innate and acquired immunity, as well as with non-immune tissue-specific cell types. This article reviews and discusses the evidence that $\mathrm{MC}$ membrane-expressed molecules play a central role in regulating $\mathrm{MC}$ priming and activation and in the modulation of innate and adaptive immune response not only against host injury, but also in peripheral tolerance and tumor-surveillance or -escape. The complex expression of MC surface molecules may be regarded as a measure of connectivity, with altered patterns of cell-cell interaction representing functionally distinct $\mathrm{MC}$ states. We will focalize our attention on roles and functions of recently discovered molecules involved in the cross-talk of MCs with other immune partners.

Keywords: mast cell, cell-cell interaction, adaptive immunity, innate immunity

\section{INTRODUCTION: ORIGIN, DISTRIBUTION AND FUNCTIONAL HETEROGENEITY}

To develop an effective immune response, the cells of the immune system are required to communicate between each other through secretion of soluble mediators and direct cell-cell interaction. Among the cells of the immune system, mast cell (MC) appears to be one of the most powerful in terms of ability to respond to multiple stimuli and to selectively release different types and amounts of mediators (reviewed in Galli et al., 2005b).

Research on MC physiopathology has changed our perception of the role that MCs play within the immune system. Indeed, their functions extend through all the stages of the immune response, ranging from shaping the response against pathogens, regulating both innate and acquired immune cell functions, to supporting regulatory cells in the maintenance of tissue-tolerance.

MCs originate from a multipotent hematopoietic progenitors in bone marrow, and then migrate through blood to tissues where they mature (Hallgren and Gurish, 2011). In mice, an hematopoietic stem cell progresses to a multipotent progenitor, a common myeloid, and a granulocyte/monocyte progenitor (Chen et al., 2005). A monopotent MC progenitor is found in bone marrow and intestine, and a common basophil/MC progenitor is also found in mouse spleen (Chen et al., 2005). After their homing in the tissues, maturation of the MC precursors is dependent on stem cell factor (SCF) expressed on the surface of fibroblasts, stromal cells, and endothelial cells (Arinobu et al., 2005).

MCs are positioned throughout the vascularized tissues and serosal cavities where they constitute one of the first cell types of the immune system able to interact with allergens and antigens
(Galli et al., 2008a). Within body tissues, micro-environmental stimuli control MC phenotypic profile leading to subtype differences from a common progenitor (Moon et al., 2010). Historically, the classification of rodent MC subtypes has been based on phenotypic differences between connective tissue MCs (CTMCs), found in the skin and peritoneal cavity, and mucosal MCs (MMCs), which are mainly present in the intestinal lamina propria. There are, however, different phenotypic characteristics between these two populations and also differences in functions, histochemical staining, content of proteases, and reactivity to selected secretagogues and anti-allergic drugs. MMCs express MC protease (MMCP)-1 and -2, while CTMCs are positive for MMCP-4, -5, -6 , and carboxypeptidase A. MMCs expand remarkably during $\mathrm{T}$ cell-dependent immune responses to certain parasites while CTMCs exhibit little or no T cell dependence (Moon et al., 2010). Human MCs also exhibit heterogeneity and are thus classified by their content of serine proteases as tryptase-only MCs $\left(\mathrm{MC}_{\mathrm{T}}\right)$, which predominate in the alveolar septa and in the small intestinal mucosa, chymase-only MCs $\left(\mathrm{MC}_{\mathrm{C}}\right)$, present in synovial tissue, or both tryptase- and chymase-positive $\mathrm{MCs}\left(\mathrm{MC}_{\mathrm{TC}}\right)$ which localize in skin, tonsils and small intestinal submucosa (Irani et al., 1986; Irani and Schwartz, 1994).

\section{MAST CELL COMMUNICATION WITHIN IMMUNE SYSTEM VIA SOLUBLE MEDIATORS}

MC heterogeneity depending on the tissue distribution, is reflected by their ability to react to multiple stimuli (Frossi et al., 2004) and by the numerous immunoglobulin $\mathrm{E}$ (IgE)-dependent and -independent activation pathways. A plethora of membrane 
receptors can regulate $\mathrm{MC}$ activation: $\mathrm{Fc} \varepsilon \mathrm{RI}$ and $\mathrm{Fc} \gamma$ receptors, Toll like receptors (TLRs), complement receptors, cytokine and chemokine receptors, and hormone receptors (Zhao et al., 2001; Theoharides et al., 2004; Galli et al., 2005b) as summarized in Table 1. Depending on the type, property, strength, and combination of the stimuli they receive, MCs secrete a diverse and wide range of biologically active products that can trigger, direct, or suppress the immune response (Frossi et al., 2004). MC soluble products, listed in Table 2, can be divided into two categories: (a) preformed mediators, such as histamine, proteoglycans, and neutral proteases and certain cytokines, in particular tumor necrosis factor-alpha (TNF- $\alpha)$, that are rapidly and instantaneously released upon MC activation; (b) newly synthesized mediators, such as cytokines, chemokines, lipid mediators, growth and angiogenic factors that start to be synthesized after MC activation (Galli et al., 2005a; Metz and Maurer, 2007). Although these products are all important in both innate and acquired immunity, the rapid release of $\mathrm{MC}$ mediators is crucial for the initiation of the immune response at the site of infection since they are able to modulate the immune-cell trafficking and to provide co-stimulatory signals for cell activation. In particular, focusing on rapidly released mediators, histamine is the most abundant vaso-active amine that is stored in MC granules, and it targets specific receptors on several cell types. It binds to histamine receptors on airway smooth muscle cells and on gastrointestinal cells and induces contraction and vasospasm. In addition, it has been reported that histamine is able to drive dendritic cell (DC) migration and activation (Caron et al., 2001). Among early released MC products, TNF- $\alpha$ is a granule-stored preformed cytokine that plays a crucial role during innate immunity as, by inducing the early influx of neutrophils, it promotes the clearance of pathogens and improves survival and morbidity (Henz et al., 2001). Serine proteases, chymase and tryptase, and the metalloprotease carboxypeptidase A are the major pre-synthesized granule components. They directly protect against parasites and venoms (carboxypeptidase A; Metz and Maurer, 2007), but also favor the expulsion of nematodes by increasing intestinal permeability (mouse MC protease-1, mMCP-1; McDermott et al., 2003), by allowing tissue remodeling, fibronectin turn-over (mMCP-4; Tchougounova et al., 2003), and induction of persistent influx of neutrophils with long lasting inflammation (mMCP-6; Huang et al., 1998).

Arachidonic acid-derived prostaglandins and leukotrienes are de novo synthesized metabolites of cyclooxygenase and lipooxygenase enzymes. They improve the innate response by increasing MC numbers at inflammation sites, through the recruitment of immature MCs and/or progenitors (Weller et al., 2005). MCsecreted cathelicidins reduce bacterial numbers, thus directly driving bacterial clearance (Di Nardo et al., 2003). MC-secreted compounds also contribute to the acquired immune response, serving as mediators for $\mathrm{B}$ and $\mathrm{T}$ cell recruitment and activation. MC-derived leukotriene B4 induces chemotaxis of effector CD8 ${ }^{+}$ $\mathrm{T}$ cells in the course of allergic inflammation (Ott et al., 2003), while MC-derived TNF- $\alpha$ is crucial in the recruitment of CD4 ${ }^{+}$

Table 1 | MC membrane-bound receptors.

\begin{tabular}{|c|c|c|}
\hline Receptor family & Members & Reference \\
\hline \multicolumn{3}{|l|}{ FcR } \\
\hline FceR & FcERI & Kinet (1999) \\
\hline TLR & TLR1, TLR2, TLR3, TLR4, TLR5, TLR6, TLR7, TLR8, TLR9, TLR10 ${ }^{\mathrm{a}}$ & Marshal et al. (2009) \\
\hline $\mathrm{MHC}$ & MHC class I, MHC class II & Svensson et al. (1997) \\
\hline Chemokine receptor & $\begin{array}{l}\text { CCR1, CCR3, CCR4, CCR5,CCR7, CXCR1, CXCR2, CXCR3, CXCR4, CXCR6, } \\
\text { CX3CR1 }\end{array}$ & Juremalm and Nilsson, (2005) \\
\hline \multicolumn{3}{|c|}{ RECEPTOR FOR ENDOGENOUS MOLECULES } \\
\hline Histamine receptor & $\mathrm{H} 1 / \mathrm{H} 2 / \mathrm{H} 3 / \mathrm{H} 4$ receptor & Sander et al. (2006) \\
\hline \multicolumn{3}{|c|}{ CO-STIMULATORY MOLECULES } \\
\hline TNF/TNFR family members & CD40L, OX40L, 4-1BB, GITR, CD153, Fas, TRAIL-R & $\begin{array}{l}\text { Juremalm and Nilsson (2005), Nakae et al. } \\
\text { (2006), Nakano et al. (2009) }\end{array}$ \\
\hline B7 family member & CD28, ICOSL, PD-L1, PD-L2 & \\
\hline TIM family members & TIM1, TIM3 & \\
\hline Notch family members & Notch1, Notch2 & \\
\hline
\end{tabular}

Some molecules have been detected only in studies on human ${ }^{a}$ or murine ${ }^{b}$ MCs where not indicated, molecules are expressed in both species. 
Table 2 | Major MC-derived mediators.

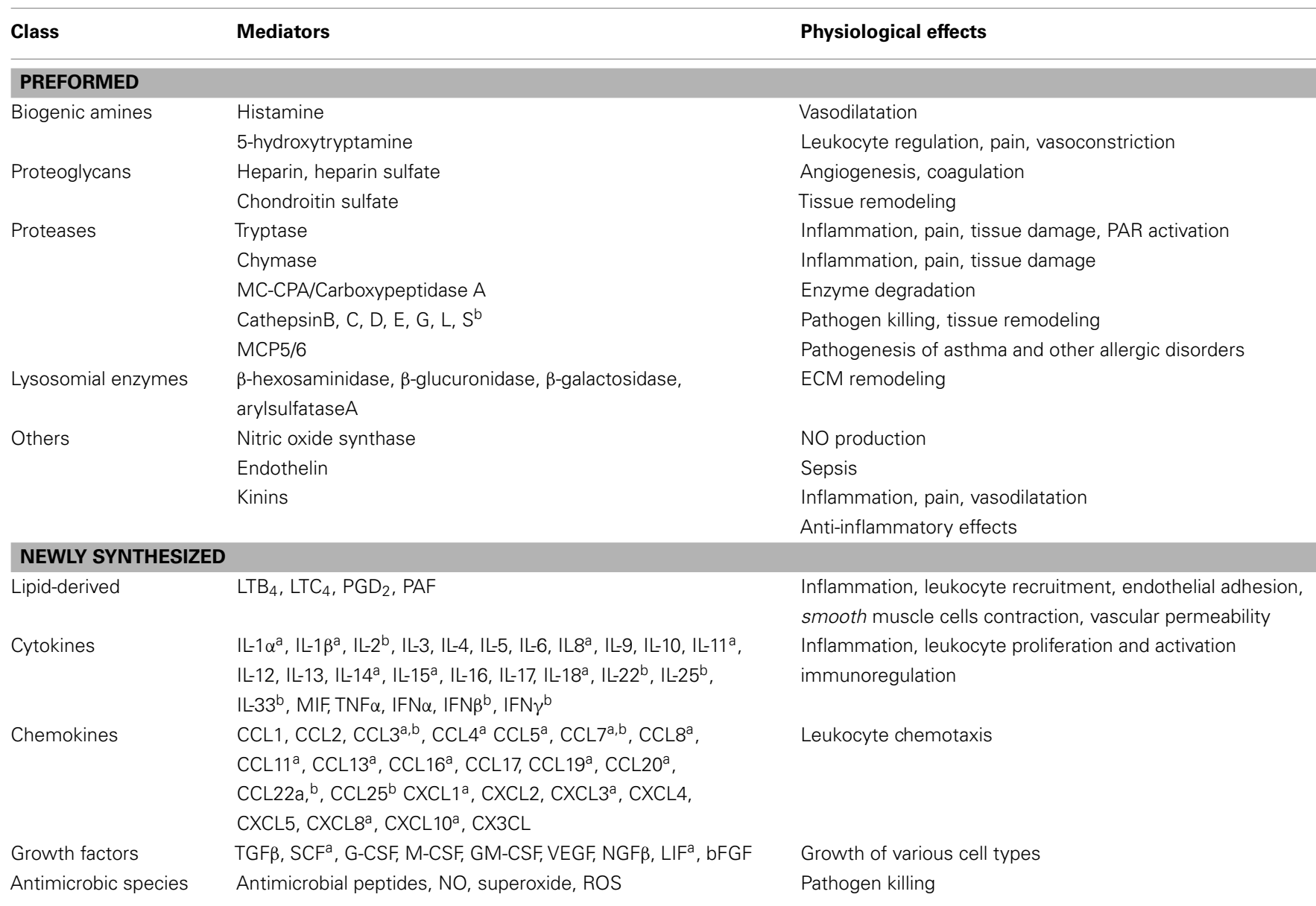

Some mediators have been detected only in studies on human ${ }^{a}$ or murine ${ }^{b} \mathrm{MCs}$ or not investigated ${ }^{\text {ni }}$ where not indicated molecules are expressed in both species. General references: Galli et al. (2005a), Metz and Maurer (2007).

T cells to draining lymph nodes, during Escherichia coli infection (McLachlan et al., 2003). In addition, a TNF- $\alpha$-dependent effect on Langerhans cells that migrate from skin to draining lymph nodes following response to bacterial peptidoglycan has been reported (Jawdat et al., 2004).

The anti-inflammatory properties of MCs were explored in vivo, providing evidence about MC ability to suppress the development and magnitude of the adaptive immune response (reviewed in Galli et al., 2008a). Indeed, MC-derived histamine seems to be responsible of the systemic immunosuppression of contact hypersensitivity (CHS) responses achieved by the ultraviolet B (UVB) irradiation of the skin (Hart et al., 1998), while MC-derived IL-10 limits the response to allergic contact dermatitis (Grimbaldeston et al., 2007). MC-derived IL-10 has been implicated as a mechanism of negative immune-modulatory effects following Anopheles mosquito bites or in peripheral tolerance to skin allograft (Depinay et al., 2006; Lu et al., 2006), but other soluble or surface molecules might be responsible for MC negative immunomodulatory functions. The mechanisms controlling the immunosuppressive function of MCs are under investigation and might be considered for pharmacological intervention to modulate the immune system in inflammatory diseases.

\section{PATTERN OF MC MEMBRANE-BOUND MOLECULES REGULATING IMMUNOLOGICAL EFFECTOR FUNCTIONS}

Mast cells express a broad array of cell surface receptors and ligands involved in cell-cell and cell-extracellular-matrix adhesion, which mediate the delivery of co-stimulatory signals that empower these cells to interact with different immune- and nonimmune cells. These interactions are often bi-directional, fulfilling mutually regulatory, and/or modulatory roles, including influences on several cellular processes, such as proliferation and gene transcription. Accordingly, MC effector function plasticity might depend not only on the activatory/inhibitory signals and on the specific released mediators, but also on the secondary, costimulatory signals that they receive from their cellular partners in the microenvironment. Thus, MCs specialize in establishing reliable, wideband communication with other cells, orchestrating the overall immune response (Bachelet and Levi-Schaffer, 2007). 
Here, we aim to describe the recent advances in contactmediated co-stimulatory pathways connecting MC with innate and acquired immune cells. The molecules that mediate the crosstalk between MCs and their cell partners are all listed in Table 3.

\section{AND INNATE IMMUNE CELLS MCs and dendritic cells}

The close apposition of MCs and DCs in sub-epithelial areas as sentinel of invading antigen, has led investigators to propose their potential functional partnership in modulation of the immune responses to environmental changes (Mazzoni et al., 2006; Otsuka et al., 2011). DCs do not only represent a single uniform population but display a considerable degree of heterogeneity which complicates the network of interactions with MCs subtypes (Shortman and Liu, 2002). MCs express several molecules (TNF- $\alpha$, histamine, PGD2, chemokines) that might affect DC function in peripheral inflamed tissues. Both human and mouse IgE-activated MCs have been widely implicated in the process of DC mobilization from tissue to secondary lymphoid organs (Jawdat et al., 2004; Suto et al.,
2006; Dawicki et al., 2010), DC maturation (Skokos et al., 2003; Kitawaki et al., 2006), and DC capacity to promote T cell responses (Kitawaki et al., 2006; Leonard et al., 2006; Mazzoni et al., 2006; Dudeck et al., 2011).

To date, while exchange of soluble mediators between MCs and DCs has been well characterized, data regarding MCs-DCs direct cross-talk are very scarce. Nonetheless, some clues are been unveiled.

In an in vitro cultured human system, a combinatorial effect of various factors which are able to activate human cord bloodderived MCs, including those acting in a cell contact-dependent fashion, are required for the optimal induction of Th2-promoting human monocyte-derived DCs (Kitawaki et al., 2006). Moreover, it has been shown that murine peritoneal MCs (PCMCs) can undergo a dynamic interaction with immature DCs, inducing DC maturation and the release of the T cell modulating cytokines IFN$\gamma$, IL-2, IL- 6 , and TGF- $\beta$. Such PCMCs-primed DCs subsequently induced $\mathrm{T}$ cell proliferation and Th1 and Th17 responses (Dudeck et al., 2011). Studies in mice report that bone marrow-derived MCs

Table 3 | MC physical interactions with other immune cells.

\begin{tabular}{|c|c|c|c|c|c|}
\hline Cell types & MC molecule & $\begin{array}{l}\text { Partner } \\
\text { molecule }\end{array}$ & Effect on MC & Effect on partner cell & Reference \\
\hline MC-DC & ICAM-1 & LFA-1 & $\uparrow \mathrm{Ca}^{++}$influx & $\uparrow$ Maturation and chemotaxis & Otsuka et al. (2011) \\
\hline MC-MDSC & n.i. & n.i. & $\uparrow$ Recruitment and survival & $\begin{array}{l}\uparrow \text { Migration and suppression } \\
\text { activity }\end{array}$ & Yang et al. (2010) \\
\hline \multirow[t]{2}{*}{ MC-NK } & CXCL8 & CXCR1 & n.i. & $\uparrow$ Recruitment & Burke et al. (2008) \\
\hline & OX40L & $\mathrm{O} \times 40$ & n.i. & IFN $\gamma$ production & Vosskuhl et al. (2010) \\
\hline \multirow[t]{3}{*}{ MC-Eos } & CD226 & CD112 & $\uparrow$ Degranulation & n.i. & Bachelet et al. (2006) \\
\hline & CD48 & $2 B .4$ & n.i. & $\uparrow$ Survival & Elishmereni et al. (2010) \\
\hline & n.i. & n.i. & Transfer of tryptase & $\begin{array}{l}\uparrow E P O \text { and cytokine release, } \\
\text { transfer of EPO }\end{array}$ & Minai-Fleminger et al. (2010) \\
\hline \multirow[t]{6}{*}{$\mathrm{MC}-\mathrm{CD} 4{ }^{+} \mathrm{T}$} & ICAM-1 & LAF-1 & $\begin{array}{l}\uparrow \text { Degranulation and cytokine } \\
\text { release }\end{array}$ & $\uparrow$ Activation and proliferation & $\begin{array}{l}\text { Inamura et al. (1998), Mekori } \\
\text { and Metcalfe (1999) }\end{array}$ \\
\hline & ICAM-1 & LFA-1 & Adhesion to endothelial cell & n.i. & Brill et al. (2004) \\
\hline & LT $\beta R$ & LT $\beta R$ ligand & $\uparrow$ Cytokine release & n.i. & Stopfer et al. (2004) \\
\hline & OX40L & OX40 & n.i. & $\uparrow$ Activation and proliferation & $\begin{array}{l}\text { Frandji et al. (1993), Fox et al. } \\
\text { (1994) }\end{array}$ \\
\hline & MHC-II & TCR & n.i. & Cell activation & Kashiwakura et al. (2004) \\
\hline & ICOSL & ICOS & n.i. & Switch to IL-10 regulatory $T$ & $\begin{array}{l}\text { Gaudenzio et al. (2009), } \\
\text { Kambayashi et al. (2009), } \\
\text { Valitutti and Espinosa (2010), } \\
\text { Nie et al. (2011) }\end{array}$ \\
\hline \multirow[t]{2}{*}{$\mathrm{MC}-\mathrm{CD}+8$} & $\mathrm{MHC}-\mathrm{I}$ & TCR & n.i. & Cell activation & Malaviya et al. (1996) \\
\hline & $\mathrm{MHC}-\mathrm{I}$ & TCR & $\begin{array}{l}\uparrow \text { Expression of } \\
\text { co-stimulatory molecules and } \\
\text { degranulation }\end{array}$ & Cell activation & Stelekati et al. (2009) \\
\hline \multirow[t]{2}{*}{ MC + Treg } & OX40L & OX40 & $\downarrow$ Degranulation & $\begin{array}{l}\downarrow \text { Suppressive activity, } \\
\text { conversion to Th17 }\end{array}$ & $\begin{array}{l}\text { Gri et al. (2008), Piconese } \\
\text { et al. (2009) }\end{array}$ \\
\hline & TGF $\beta R$ & $\begin{array}{l}\text { TGF } \beta \text { membrane- } \\
\text { bound }\end{array}$ & $\begin{array}{l}\downarrow \text { Degranulation, } \uparrow \mid \mathrm{IL} 6 \\
\text { production }\end{array}$ & $\downarrow$ Suppressive activity & Ganeshan and Bryce (2012) \\
\hline$M C+B$ & CD40L & CD40 & n.i. & $\uparrow$ Proliferation and Ig switch & $\begin{array}{l}\text { Gauchat et al. (1993), Merluzzi } \\
\text { et al. (2010) }\end{array}$ \\
\hline
\end{tabular}

n.i., not investigated. 
(BMMCs) promote the maturation and chemotactic activity of bone marrow DCs through direct cell-cell interaction during the sensitization phase of CHS response. BMMCs and bone marrow derived immature DCs interact throughout intracellular adhesion molecule (ICAM)-1 and lymphocyte function-associated antigen (LFA-1) enhancing DC expression of the CD40, CD80, CD86, and CCR7 co-stimulatory molecules, thus promoting maturation and chemotaxis of DCs (Otsuka et al., 2011). It is possible to argue that DCs make use of MC-induced active LFA-1 to control the contact duration with naive $\mathrm{T}$ cells and to promote $\mathrm{T}$ cell priming (Balkow et al., 2010). On the other hand, co-cultures of stimulated bone marrow derived DCs with BMMCs increases calcium influx and up-regulate membrane-bound TNF- $\alpha$ (Otsuka et al., 2011).

\section{MCs and natural killer cells}

Concerning the cellular interactions that play a role in innate immune defense, emerging evidences show MC-dependent natural killer (NK) cell recruitment and activation. NK cells are granular cytotoxic and circulating lymphocytes involved in the clearance of transformed and pathogen-infected cells. As a part of the innate immune system, their recruitment to the site of infection is mediated by a large spectrum of chemokines which bind to the chemokine receptors, CCR2, CCR5 and CXCR3 on NK cells. Activated MCs can induce NK cell accumulation in different disease models. For instance, immune surveillance by MCs is important for NK cell recruitment and viral clearance during Dengue infection (St John et al., 2011). Human cord blood-derived MCs stimulated with virus-associated TLR3 agonist can recruit human NK via the CXCL8 and CXCR1 axis, underlining MC role as sentinel cell during early viral infections (Burke et al., 2008). Lipopolysaccharide (LPS)-activated BMMCs induce cell contact-dependent IFN- $\gamma$ secretion by NK cells, without affecting cell-mediated cytotoxicity. Cellular interaction is partly mediated by OX40L expression on MCs (Vosskuhl et al., 2010). In the cited work, authors underline that different MC signals of activation confer different results in terms of NK activation. In fact, in addition to LPS, stimulation of MCs via TLR3 and TLR9, but not with IgE/antigen, amplifies IFN- $\gamma$ secretion by NK cells (Vosskuhl et al., 2010). Similarly, in a model of hepatocarcinoma, MC protumoral role is associated with reduction of NK cell number and activation. This effect was due to the fact that, in the tumor micro environment, SCF-activated MCs release adenosine that inhibit production of IFN- $\gamma$ by NK cells (Huang et al., 2008). Enhanced CCL3-mediated recruitment of NK cells is instead observed in a orthotopic melanoma model in which TLR2-activated MCs exert anticancer properties by secreting large amounts of this chemokine (Oldford et al., 2010).

\section{MCs and eosinophils}

Mast cells and eosinophils (Eos) co-exist in tissues during the late and chronic phases of allergic reaction where the intracellular events following IgE/Ag-induced MC activation lead to the release of pro-inflammatory mediators, which cause the immediate, early-phase of the allergic process within minutes of allergen exposure (Williams and Galli, 2000), and induce the recruitment of inflammatory cells, i.e., macrophages, T cells, Eos, basophils, and perhaps invariant NK T cells (Galli et al., 2008b). These cells, and mainly the Eos, cause the onset of the late phase of allergic response that usually occurs a few hours later (Metz et al., 2007). Nevertheless, a clear cut interplay between MCs and Eos has been proven not only in allergic inflammatory tissues (Minai-Fleminger and Levi-Schaffer, 2009; Wong et al., 2009), but also in gastric carcinoma (Caruso et al., 2007), chronic gastritis (Piazuelo et al., 2008), Crohn's disease, and Ascaris infection (Beil et al., 2002), leading to new perspectives of the current research in this area.

Eos and MCs may mutually influence each other functions by a variety of paracrine and receptor/ligand-dependent signals. In this context, some surface molecules are potential candidates to mediate MC-Eos physical contact. A considerable advance in understanding MC-Eos interaction in a human system was made by Levi-Schaffer and coworkers. CD48 and 2B4 expressed by human cord blood-derived MCs and peripheral Eos, respectively mediate the MC-Eos physical interface as a co-stimulatory signaling switch, inducing effect on Eos viability and activating Eos to release eosinophil peroxidase, IFN- $\gamma$ and IL-4 (Elishmereni et al., 2010). Similarly, evidence for a role of CD226/CD112 interaction in Eos-dependent enhancement of IgE-induced MCs activation has been described (Bachelet et al., 2006). Other ligand-receptor interactions between MCs and Eos seem to be mediated through LFA-1 and ICAM-1. This pathway can be activated upon MC degranulation and results in the recruitment of eosinophils at the site of inflammation (Elishmereni et al., 2010). Moreover, by transmission electron microscopy it has been possible to demonstrate that human peripheral blood Eos and cord-blood-derived MC functionally adhere to each other as Eos peroxidase (EPO) is transferred from Eos to MCs and tryptase from MCs to Eos, thus indicating that MCs and Eos show signs of reciprocal activation (Minai-Fleminger et al., 2010).

\section{MCs and neutrophils}

Polymorphonuclear neutrophils (PMNs) constitute the most abundant leukocyte population in the peripheral blood of humans, make a highly significant contribution to the host defense, and are particularly well studied in the context of bacterial infection. However, PMN are more versatile as there is increasing evidence for their participation in acute and chronic inflammatory processes, in the regulation of the immune response, in angiogenesis, and in the interaction with tumors (Fridlender et al., 2009; Mantovani et al., 2011). PMNs have emerged as an important component of effector and regulatory circuits in the innate and adaptive immune systems. In contrast to the traditional view of these cells as short-lived effectors, evidence now indicates that they have diverse functions. By responding to tissue- and immune cell-derived signals and by undergoing polarization, $\mathrm{PMNs}$ are reminiscent of macrophages (Fridlender et al., 2009; Biswas and Mantovani, 2010). PMNs engage in bi-directional interactions with diverse components of both the innate and adaptive immune systems and can differentially influence the response depending on the pathological context. With the advent of MC-deficient mice and the ability to selectively reconstitute their deficiency it has been possible to show that MCs are critical for the PMN activation. Thus, in a model of immune complex-mediated peritonitis, the rapid recruitment of PMNs turns out to be initiated by LT produced by MCs, which are strategically located at the host-environment 
interface (Ramos et al., 1990, 1991). In addition, in the same model, the recruitment of PMN at late phase was dependent also on MCs, and on MCs-released TNF- $\alpha$ (Zhang et al., 1992). The unique ability of MCs to store and immediately release TNF- $\alpha$ on demand, and subsequently as newly synthesized inflammatory molecule, is essential for the rapid onset and for the sustaining of inflammatory reactions (Wershil et al., 1991). A cornerstone in this context was the observation that MCs and MC-derived TNF- $\alpha$ initiate the life-saving inflammatory response rapidly upon encountering microbes and microbial constituents through the influx of neutrophils in mouse models for acute bacterial infections (Echtenacher et al., 1996). In murine infectious peritonitis it has been published that, besides TNF- $\alpha$, several other MC-derived molecules have a role in the recruitment of PMNs. In fact, MC-derived LT (Ramos et al., 1991), mouse MC protease 6 (mMCP-6; Caughey, 2007), and the chemokine MIP-2 (CXCL2; Wang and Thorlacius, 2005) are critical for a rapid and protective influx of PMNs. The available data suggest that mMCP-6 triggers the release of MIP2 from endothelial cells ("activation" of endothelial cells), which in turn enhances the release of MC-derived TNF- $\alpha$, followed by sustained secretion of LT.

However, in this contest in which a clear functional interaction between MC and PMNs has been established, receptors-ligand pair that might physically mediate the cross-talk between these two cell populations have not yet been described.

\section{MCs and myeloid derived suppressor cells}

A complex network of cellular interactions characterizes tumor microenvironment with the presence of immune-suppressive and pro-inflammatory cells. MCs are known actors in cancer setting thanks to their ability to directly influence tumor growth, angiogenesis, and tissue remodeling and to exert an indirect function by immune-modulating cancer microenvironment. A closed loop amongst MCs and myeloid derived suppressor cells (MDSCs), also involving regulatory $\mathrm{T}$ (Treg) cells, has been recently described in murine hepatocarcinoma tumor microenvironment. MCs promote the migration and suppressor function of tumor MDSCs by CCL-2 and 5-lipoxygenase release, further exacerbating tumor inflammatory microenvironment. Indeed, MCs stimulate MDSCs to secrete the pro-inflammatory cytokine IL-17 which stimulate Treg cells to release IL-9 which in turn, strengthen the survival and protumoral effect of MCs (Yang et al., 2010; Cheon et al., 2011).

These are preliminary studies that disclose a novel relationship between MDSCs, MCs, and Treg cells. Further analysis will determine whether these cells physically interact through co-stimulatory molecules.

\section{AND ADAPTIVE IMMUNE CELL MCs and effector T cells}

The close physical apposition between $\mathrm{MC}$ and $\mathrm{T}$ cell has been observed during T cell-mediated inflammatory processes (Mekori and Metcalfe, 1999), such as cutaneous delayed-type hypersensitivity (Dvorak et al., 1976; Waldorf et al., 1991), sarcoidosis (Bjermer et al., 1987), and in chronic inflammatory processes associated with the pathology of inflammatory bowel disease and rheumatoid arthritis (Marsh and Hinde, 1985; Malone et al., 1986). Moreover, morphological studies have revealed that MCs reside in close physical proximity to $\mathrm{T}$ cells in inflamed allergic tissues and at sites of parasitic infections (Friedman and Kaliner, 1985; Smith and Weis, 1996).

Some of such influences have been attributed to the biological effects of a wide range of soluble mediators; however increasing amounts of literature documents recognize the importance of intercellular communication involving the binding of cell surface molecules.

Early studies demonstrated that intercellular contacts between $\mathrm{MC}$ and $\mathrm{T}$ cell lines are able to activate MC transcription machinery (Oh and Metcalfe, 1996). Adhesion of HMC-1 human MC line, or murine BMMCs, to activated T lymphocytes induces $\mathrm{MC}$ degranulation and TNF- $\alpha$ production (Bhattacharyya et al., 1998). Moreover, the MC-T cell cross-talk results in the release of matrix metalloproteinase (MMP)-9 and the tissue inhibitor of metalloproteinase 1 from HMC- 1 human MCs or from mature peripheral blood-derived human MCs. This effect, as well as the secretion of $\beta$-hexosaminidase and several inflammatory cytokines (TNF- $\alpha$, IL-4, and IL-6), is mediated by a direct contact of activated, but not resting, T cell membranes with MCs (Baram et al., 2001). In accordance with these findings, a recent study revealed that activated $\mathrm{T}$ cell microparticles, small membrane-bound structures released from cells during activation or apoptosis, are able to induce the production of soluble mediators from LAD2 human cell line and human cord blood-derived MC cultures. By releasing microparticles, T cells may convey surface molecules and activate distant MCs within the same inflammatory site (Shefler et al., 2010). Other heterotypic adhesion-induced effects on $\mathrm{MC}$ activation have been described. The proximity of activated T lymphocytes to HMC-1 promotes MC adhesion to the receptor of endothelial cells as well as to the extracellular matrix ligands (Brill et al., 2004).

The adhesion pathway mediated by LFA-1 and its ligand ICAM1 induced FceRI-dependent murine BMMC degranulation after heterotypic aggregation with activated $\mathrm{T}$ cells and was the first membrane-bound pathway involved in $\mathrm{MC} / \mathrm{T}$ cell cross-talk to be described (Inamura et al., 1998). In addition, lymphotoxin- $\beta$ receptor (LT $\beta \mathrm{R}$ ) expressed on murine BMMCs can be triggered by LT $\beta R$ ligands expressed by $\mathrm{T}$ cell lines and transduces a costimulatory signal leading to the release of cytokines (IL-4, IL-6, TNF- $\alpha$ ) and chemokines (CXCL2 and CCL5) from ionomycinactivated BMMCs (Stopfer et al., 2004). Moreover, the engagement of OX40 on activated $\mathrm{CD}^{+}{ }^{+} \mathrm{T}$ cells by OX40L-expressing MCs, together with the secretion of soluble MC-derived TNF- $\alpha$, costimulates proliferation and cytokine production from activated $\mathrm{CD}^{+} \mathrm{T}$ cells (Nakae et al., 2006). Similar results were also established in a culture system of human tonsillar MCs and human $\mathrm{T}$ cells which confirmed the enhancement of $\mathrm{T}$ cell proliferation upon direct OX40/OX40L engagement demonstrating the presence of a bi-directional cellular cross-talk among these cell types (Kashiwakura et al., 2004). The existence of functional MC-T cells interaction also arises from the observation that murine BMMCs could present antigenic peptides to $\mathrm{T}$ cell lines and $\mathrm{CD}^{+}{ }^{+} \mathrm{T}$ cell hybridoma (Frandji et al., 1995, 1996). MHC-II-dependent antigen presentation to $\mathrm{CD} 4^{+} \mathrm{T}$ cells by MCs was also demonstrated in rat and human cell systems (Fox et al., 1994; Poncet et al., 1999) reinforcing the concept that MCs can serve as unconventional antigen presenting cells for $\mathrm{T}$ lymphocytes (Valitutti and Espinosa, 
2010). More recently, it has been proposed the possibility that MCs can be primed to acquire APC phenotype. To date, inducible expression of MHC-II molecules, MHC-II associated molecules as well as OX40L and PD-L1, by murine BMMCs, spleen-derived MCs, and peritoneal MCs has been reported in response to various in vitro treatments (Gaudenzio et al., 2009; Kambayashi et al., 2009; Nakano et al., 2009). It has been shown that Notch signaling induces MHC-II and OX40L expression and can thus elicit the commitment of BMMC to an APC population, which promotes the differentiation of naive $\mathrm{CD} 4^{+} \mathrm{T}$ cells toward conventional Th2 cells (Nakano et al., 2009). It also appears that MHC-II expression grants MCs the ability to effectively support $\mathrm{T}$ cell proliferation and effector functions and causes expansion of Treg cells (Kambayashi et al., 2009). In addition, a recent work provides experimental morphological evidence of direct antigen presentation by peritoneal cell-derived MCs and freshly isolated peritoneal MCs at a single-cell level, eliciting functional responses in effector $\mathrm{T}$ cells, but not in their naïve counterparts (Gaudenzio et al., 2009). Similarly, MCs are capable of inducing antigen-specific $\mathrm{CD} 8^{+} \mathrm{T}$ cell responses in vitro and in vivo. Murine BMMCs can, in fact, process Ag from phagocytosed bacteria for presentation via MHC class I molecules to T cells (Malaviya et al., 1996). Moreover, MHC class I dependent cross presentation of BMMCs and peritoneal MCs to $\mathrm{CD}^{+} \mathrm{T}$ cells was recently shown to increase $\mathrm{CD}^{+} \mathrm{T}$ cell proliferation, cytotoxic potential, and degranulation. In turn, $\mathrm{CD}^{+} \mathrm{T}$ cells induce MHC class I and 4-1BB expression on BMMCs as well as the secretion of osteopontin (Stelekati et al., 2009).

\section{MCs and natural and inducible regulatory $T$ cells}

In the complex network of immune interactions, the amount of information available on the functional interaction between MCs and immunoregulatory cells is going to increase. MCs and natural CD $25^{+}$Foxp $3^{+}$Treg cells have been demonstrated to reside in close proximity in secondary lymphoid tissues as well as in mucosal tissues (Vliagoftis and Befus, 2005; Gri et al., 2008) and to influence each others' function. Indeed, activated Treg cells caused a reduction in the expression of FceRI on murine BMMCs by contact-dependent mechanism and production of soluble factors such as TGF- $\beta$ and IL-10 (Kashyap et al., 2008). Treg cells can hinder BMMC degranulation and immediate hypersensitivity response through the engagement of OX40L on MCs (Gri et al., 2008). Treg cell-mediated inhibition of MC function is regulated at a single-cell level and is not restricted to BMMCs, but is a common feature of murine PCMCs and human LAD2 MC line (Frossi et al., 2011).

A recent study confirmed that co-culture of Treg cells with murine BMMC suppresses degranulation but primes MCs for production of IL- 6 via a contact-dependent surface-bound TGF- $\beta$ mechanism (Ganeshan and Bryce, 2012). Interestingly, in a model of colorectal cancer, highly suppressive Treg cells lose the ability to suppress human LAD2 MC degranulation (Blatner et al., 2010), suggesting that a complex interaction between MCs and Tregs within tumor microenvironment exists, although the mechanism behind these events has not been yet discovered. Conversely, MC activation breaks peripheral tolerance. Direct cell-cell contact, dependent on OX40/OX40L interaction, and T cell-derived IL-6 promotes Th17 skewing of Treg cells with loss of both Foxp3 expression and $\mathrm{T}$ cell suppressive properties in vitro. Activated MCs, Tregs, and Th17 cells display tight spatial interactions in lymph nodes hosting $\mathrm{T}$ cell priming in experimental autoimmune encephalomyelitis further supporting the occurrence of an MC-mediated inhibition of Treg suppression in the establishment of Th17-mediated inflammatory responses (Piconese et al., 2009).

Under certain conditions such as in inflammation and immune reactions, increasing expression of ICOSL might contribute to the regulatory role of MCs. Indeed, in vitro experiments and the in vivo model of neutrophilic airway inflammation, allowed the identification of an intimate link between LPS-stimulated murine BMMCs, which upregulate ICOSL surface expression, and the generation of $\mathrm{IL}-10$ producing inducible regulatory $\mathrm{CD}^{+}{ }^{+} \mathrm{T}$ cell with inhibitory ability on effector $\mathrm{T}$ cells function. Indeed, ICOSLdeficient BMMCs are not able to sustain IL-10 producing $\mathrm{T}$ cell activation (Nie et al., 2011).

\section{MCs and B cells}

Mast cells produce several cytokines, such as IL-4, IL-5, IL-6, and IL-13, that are known to regulate, directly or in combination with other factors, B cell development and function. Moreover, the CD40L co-stimulatory molecule is expressed on the surface of activated-BMMCs, skin MCs, and MCs under allergic inflammatory conditions (Gauchat et al., 1993; Pawankar et al., 1997). These data further support the existence of a functional crosstalk between these two cell types. The first evidence of an effective MC-B cell cross-talk, mediated by the physical interaction through the CD40L:CD40 axis, was reported by Gauchat and coworkers. They showed that CD40L was expressed on both freshly purified human lung MCs and on the human cell line HMC-1 and further demonstrated that these MCs can interact with B cells to induce the production of IgE, in the presence of IL-4 and in absence of T cells (Gauchat et al., 1993). Furthermore, the role of the CD40-CD40L axis in the induction of IgE production by $B$ cells was also observed in perennial allergic rhinitis (PAR), an IgE-mediated atopic disease. Nasal MCs (NMCs) from patients with PAR displayed significantly higher expression levels of FceRI, CD40L, IL-4, and IL-13 compared to NMCs from patients with chronic infective rhinitis (CIR). The essential role of CD40L in this allergic disease context was further substantiated by the finding that the IgE production was inhibited by anti-CD40L mAb (Pawankar et al., 1997). The group of Mécheri was the first to show that unstimulated BMMCs were able to induce resting B cells to proliferate and to become IgM-producing cells. In this case, B cell activation was mediated by MC-derived factors and contact between these two cell types seemed not to be required (Tkaczyk et al., 1996). Some years later, the same research group reported that membrane vesicles, released by the MC cytoplasmic granules and termed exosomes, were responsible of MC-driven B cell proliferation and activation. Interestingly, they showed that important co-stimulatory molecules, such as MHC-II, CD86, CD40, CD40L, LFA-1, and ICAM-1, were associated with exosomes (Skokos et al., 2002).

Only recently the study of the specific role of MCs in B cell growth and differentiation has been investigated more in detail. Merluzzi and coworkers proved that both resting and activated 
MCs were able to induce a significant inhibition of cell death and an increase in proliferation of naïve B cells. Such proliferation was further enhanced in activated B cells. This effect required cellcell contact and MC-derived IL-6. Activated MCs were shown to regulate $\mathrm{CD} 40$ surface expression on unstimulated $\mathrm{B}$ cells and the interaction between CD40 and CD40L on MCs, together with MCderived cytokines, were involved in the differentiation of $\mathrm{B}$ cells into $\mathrm{CD}_{138^{+}}$plasma cells and in selective IgA secretion. These data were corroborated by in vivo evidence of infiltrating MCs in close contact with IgA-expressing plasma cells within inflamed tissues (Merluzzi et al., 2010).

\section{CONCLUDING REMARIKS}

In the last few years, our perception of MCs function has dramatically changed. In fact, there has been mounting evidence that the function of these cells is not limited to acting as first line of defense against invading pathogens or as effector cells in allergy, but is extended to perform additional and unexpected activities in strict collaboration with adaptive immune and other non-immune cells. Thus, MCs together with other innate and adaptive immune cells

\section{REFERENCES}

Arinobu, Y., Iwasaki, H., Gurish, M. F., Mizuno, S., Shigematsu, H., Ozawa, H., Tenen, D. G., Austen, K. F., and Akashi, K. (2005). Developmental checkpoints of the basophil/mast cell lineages in adult murine hematopoiesis. Proc. Natl. Acad. Sci. U.S.A. 102, 18105-18110.

Bachelet, I., and Levi-Schaffer, F. (2007). Mast cells as effector cells: a co-stimulating question. Trends Immunol. 28, 360-365.

Bachelet, I., Munitz, A., Mankutad, D., and Levi-Schaffer, F. (2006). Mast cell costimulation by CD226/CD112 (DNAM1/Nectin-2): a novel interface in the allergic process. J. Biol. Chem. 281, 27190-27196.

Balkow, S., Heinz, S., Schmidbauer, P., Kolanus, W., Holzmann, B., Grabbe, S., and Laschinger, M. (2010). LFA-1 activity state on dendritic cells regulates contact duration with $\mathrm{T}$ cells and promotes T-cell priming. Blood 116, 1885-1894.

Baram, D., Vaday, G. G., Salamon, P., Drucker, I., Hershkoviz, R., and Mekori, Y. A. (2001). Human mast cells release metalloproteinase9 on contact with activated $\mathrm{T}$ cells: juxtacrine regulation by TNF-alpha. J. Immunol. 167, 4008-4016.

Beil, W. J., Mceuen, A. R., Schulz, M., Wefelmeyer, U., Kraml, G., Walls, A. F., Jensen-Jarolim, E., Pabst, R., and Pammer, J. (2002). Selective alterations in mast cell subsets and eosinophil infiltration in two complementary types of intestinal inflammation: ascariasis and Crohn's disease. Pathobiology 70, 303-313.

Bhattacharyya, S. P., Drucker, I., Reshef, T., Kirshenbaum, A. S., Metcalfe, D. D., and Mekori, Y. A. (1998). Activated $\mathrm{T}$ lymphocytes induce degranulation and cytokine production by human mast cells following cellto-cell contact. J. Leukoc. Biol. 63, 337-341.

Biswas, S. K., and Mantovani, A. (2010). Macrophage plasticity and interaction with lymphocyte subsets: cancer as a paradigm. Nat. Immunol. 11, 889-896.

Bjermer, L., Engstrom-Laurent, A., Thunell, M., and Hallgren, R. (1987). The mast cell and signs of pulmonary fibroblast activation in sarcoidosis. Int. Arch. Allergy Appl. Immunol. 82, 298-301.

Blatner, N. R., Bonertz, A., Beckhove, P., Cheon, E. C., Krantz, S. B., Strouch, M., Weitz, J., Koch, M., Halverson, A. L., Bentrem, D. J., and Khazaie, K. (2010). In colorectal cancer mast cells contribute to systemic regulatory T-cell dysfunction. Proc. Natl. Acad. Sci. U.S.A.107, 6430-6435.

Brill, A., Baram, D., Sela, U., Salamon, P., Mekori, Y. A., and Hershkoviz, R. (2004). Induction of mast cell interactions with blood vessel wall components by direct contact with intact $\mathrm{T}$ cells or $\mathrm{T}$ cell membranes in vitro. Clin. Exp. Allergy 34, 1725-1731.

Burke, S. M., Issekutz, T. B., Mohan, K., Lee, P. W., Shmulevitz, M., and Marshall, J. S. (2008). Human

orchestrate complex functional programs to promote host defense, to control the development of self-tolerance, and to avoid autoimmunity. In this context, the gene expression pattern, the phenotype, as well as MC function must rapidly change in a coordinate, time-dependent manner in response to micro-environmental soluble and cellular signals. In view of their extensive assortment of membrane receptors able to mediate delivery of co-stimulatory signals, of molecules involved in cell-extracellular-matrix adhesion and in cell-cell contacts and of soluble pro- and anti-inflammatory mediators, MC may profoundly influence the development, intensity, and duration of adaptive immune responses that ultimately serve for host defense, allergy, and autoimmunity. Considering the continuously emerging findings in the field, it is predictable that in the next years we will assist to the discovery of additional, unsuspected biological features that MCs possess.

\section{ACKNOWLEDGMENTS}

This work was supported by the COST Action BM1007 (Mast cells and basophils - targets for innovative therapies) of the European Community.

mast cell activation with virusassociated stimuli leads to the selective chemotaxis of natural killer cells by a CXCL8-dependent mechanism. Blood 111, 5467-5476.

Caron, G., Delneste, Y., Roelandts, E., Duez, C., Bonnefoy, J. Y., Pestel, J., and Jeannin, P. (2001). Histamine polarizes human dendritic cells into Th2 cell-promoting effector dendritic cells. J. Immunol. 167, 3682-3686.

Caruso, R. A., Fedele, F., Zuccala, V., Fracassi, M. G., and Venuti, A. (2007). Mast cell and eosinophil interaction in gastric carcinomas: ultrastructural observations. Anticancer Res. 27, 391-394.

Caughey, G. H. (2007). Mast cell tryptases and chymases in inflammation and host defense. Immunol. Rev. 217, 141-154.

Chen, C. C., Grimbaldeston, M. A., Tsai, M., Weissman, I. L., and Galli, S. J. (2005). Identification of mast cell progenitors in adult mice. Proc. Natl. Acad. Sci. U.S.A. 102, 11408-11413.

Cheon, E. C., Khazaie, K., Khan, M. W., Strouch, M. J., Krantz, S. B., Phillips, J., Blatner, N. R., Hix, L. M., Zhang, M., Dennis, K. L., Salabat, M. R. Heiferman, M., Grippo, P. J., Munshi, H. G., Gounaris, E., and Bentrem, D. J. (2011). Mast cell 5-lipoxygenase activity promotes intestinal polyposis in APCDelta468 mice. Cancer Res. 71, 1627-1636.

Collington, S. J., Williams, T. J., and Weller, C. L. (2011). Mechanisms underlying the localisation of mast cells in tissues. Trends Immunol. 32, 478-485.

Dawicki, W., Jawdat, D. W., Xu, N., and Marshall, J. S. (2010). Mast cells, histamine, and IL- 6 regulate the selective influx of dendritic cell subsets into an inflamed lymph node. J. Immunol. 184, 2116-2123.

Depinay, N., Hacini, F., Beghdadi, W., Peronet, R., and Mecheri, S. (2006). Mast cell-dependent down-regulation of antigen-specific immune responses by mosquito bites. J. Immunol. 176, 4141-4146.

Di Nardo, A., Vitiello, A., and Gallo, R. L. (2003). Cutting edge: mast cell antimicrobial activity is mediated by expression of cathelicidin antimicrobial peptide. J. Immunol. 170, 2274-2278.

Dudeck, A., Suender, C. A., Kostka, S. L., Von Stebut, E., and Maurer, M. (2011). Mast cells promote Th1 and Th17 responses by modulating dendritic cell maturation and function. Eur. J. Immunol. 41, 1883-1893.

Dvorak, H. F., Mihm, M. C. Jr., and Dvorak, A. M. (1976). Morphology of delayed-type hypersensitivity reactions in man. J. Invest. Dermatol. 67, 391-401.

Echtenacher, B., Mannel, D. N., and Hultner, L. (1996). Critical protective role of mast cells in a model of acute septic peritonitis. Nature 381, 75-77.

Edling, C. E., and Hallberg, B. (2007). c-Kit - a hematopoietic cell essential receptor tyrosinekinase. Int. J. Biochem. Cell Biol. 39, 1995-1998. 
Elishmereni, M., Alenius, H. T., Bradding, P., Mizrahi, S., Shikotra, A., Minai-Fleminger, Y., Mankuta, D., Eliashar, R., Zabucchi, G., and Levi-Schaffer, F. (2010). Physical interactions between mast cells and eosinophils: a novel mechanism enhancing eosinophil survival in vitro. Allergy 66, 376-385.

Fox, C. C., Jewell, S. D., and Whitacre, C. C. (1994). Rat peritoneal mast cells present antigen to a PPDspecific $\mathrm{T}$ cell line. Cell. Immunol. 158, 253-264.

Frandji, P., Oskéritzian, C., Cacaraci, F., Lapeyre, J., Peronet, R., David, B., Guillet, J. G., and Mécheri, S. (1993). Antigen-dependent stimulation by bone marrow-derived mast cells of MHC class II-restricted T cell hybridoma. J. Immunol. 151, 6318-6328.

Frandji, P., Tkaczyk, C., Oskeritzian, C., David, B., Desaymard, C., and Mecheri, S. (1996). Exogenous and endogenous antigens are differentially presented by mast cells to CD4+ T lymphocytes. Eur. J. Immunol. 26, 2517-2528.

Frandji, P., Tkaczyk, C., Oskeritzian, C., Lapeyre, J., Peronet, R., David, B., Guillet, J. G., and Mecheri, S. (1995). Presentation of soluble antigens by mast cells: upregulation by interleukin-4 and granulocyte/macrophage colony-stimulating factor and downregulation by interferongamma. Cell. Immunol. 163, $37-46$.

Fridlender, Z. G., Sun, J., Kim, S., Kapoor, V., Cheng, G., Ling, L., Worthen, G. S., and Albelda, S. M. (2009). Polarization of tumorassociated neutrophil phenotype by TGF-beta: "N1" versus "N2" TAN. Cancer Cell 16, 183-194.

Friedman, M. M., and Kaliner, M. (1985). In situ degranulation of human nasal mucosal mast cells: ultrastructural features and cellcell associations. J. Allergy Clin. Immunol. 76, 70-82.

Frossi, B., De Carli, M., and Pucillo, C. (2004). The mast cell: an antenna of the microenvironment that directs the immune response. J. Leukoc. Biol. $75,579-585$.

Frossi, B., D'inca, F., Crivellato, E., Sibilano, R., Gri, G., Mongillo, M., Danelli, L., Maggi, L., and Pucillo, C. E. (2011). Single-cell dynamics of mast cell-CD4 + CD25+ regulatory $\mathrm{T}$ cell interactions. Eur. J. Immunol. 41, 1872-1882.

Füreder, W., Agis, H., Willheim, M., Bankl, H. C., Maier, U., Kishi, K., Müller, M. R., Czerwenka, K.,
Radaszkiewicz, T., Butterfield, J. H., Klappacher, G. W., Sperr, W. R., Oppermann, M., Lechner, K., and Valent, P. (1995). Differential expression of complement receptors on human basophils and mast cells. Evidence for mast cell heterogeneity and CD88/C5aRexpression on skin mast cells. J. Immunol. 155, 3152-3160.

Galli, S. J., Grimbaldeston, M., and Tsai, M. (2008a). Immunomodulatory mast cells: negative, as well as positive, regulators of immunity. Nat. Rev. Immunol. 8, 478-486.

Galli, S. J., Tsai, M., and Piliponsky, A. M. (2008b). The development of allergic inflammation. Nature 454, 445-454.

Galli, S. J., Kalesnikoff, J., Grimbaldeston, M. A., Piliponsky, A. M., Williams, C. M., and Tsai, M. (2005a). Mast cells as "tunable" effector and immunoregulatory cells: recent advances. Annu. Rev. Immunol. 23, 749-786.

Galli, S. J., Nakae, S., and Tsai, M. (2005b). Mast cells in the development of adaptive immune responses. Nat. Immunol. 6, 135-142.

Ganeshan, K., and Bryce, P. J. (2012). Regulatory $\mathrm{T}$ cells enhance mast cell production of IL-6 via surfacebound TGF-beta. J. Immunol. 188, 594-603.

Gauchat, J. F., Henchoz, S., Mazzei, G., Aubry, J. P., Brunner, T., Blasey, H., Life, P., Talabot, D., Flores-Romo, L., Thompson, J., Kishi, K., Butterfield, J., Dahinden, C., and Bonnefoy, J. Y. (1993). Induction of human IgE synthesis in B cells by mast cells and basophils. Nature 365, 340-343.

Gaudenzio, N., Espagnolle, N., Mars, L. T., Liblau, R., Valitutti, S., and Espinosa, E. (2009). Cell-cell cooperation at the $\mathrm{T}$ helper cell/mast cell immunological synapse. Blood 114, 4979-4988.

Gri, G., Piconese, S., Frossi, B., Manfroi, V., Merluzzi, S., Tripodo, C., Viola, A., Odom, S., Rivera, J., Colombo, M. P., and Pucillo, C. E. (2008). CD4+CD25+ regulatory T cells suppress mast cell degranulation and allergic responses through OX40OX40L interaction. Immunity 29, 771-781.

Grimbaldeston, M. A., Nakae, S., Kalesnikoff, J., Tsai, M., and Galli, S. J. (2007). Mast cell-derived interleukin 10 limits skin pathology in contact dermatitis and chronic irradiation with ultraviolet B. Nat. Immunol. 8, 1095-1104.

Hallgren, J., and Gurish, M. F. (2011). Mast cell progenitor trafficking and maturation. Adv. Exp. Med. Biol.716, $14-28$.
Hart, P. H., Grimbaldeston, M. A., Swift, G. J., Jaksic, A., Noonan, F. P., and Finlay-Jones, J. J. (1998). Dermal mast cells determine susceptibility to ultraviolet B-induced systemic suppression of contact hypersensitivity responses in mice. J. Exp. Med. 187, 2045-2053.

Henz, B. M., Maurer, M., Lippert, U., Worm, M., and Babina, M. (2001). Mast cells as initiators of immunity and host defense. Exp. Dermatol. 10 $1-10$.

Huang, B., Lei, Z., Zhang, G. M., Li, D., Song, C., Li, B., Liu, Y., Yuan, Y., Unkeless, J., Xiong, H., and Feng, Z H. (2008). SCF-mediated mast cell infiltration and activation exacerbate the inflammation and immunosuppression in tumor microenvironment. Blood 112, 1269-1279.

Huang, C., Friend, D. S., Qiu, W. T., Wong, G. W., Morales, G., Hunt, J., and Stevens, R. L. (1998). Induction of a selective and persistent extravasation of neutrophils into the peritoneal cavity by tryptase mouse mast cell protease 6. J. Immunol. 160 1910-1919.

Hudson, S. A., Herrmann, H., Du, J., Cox, P., Haddad, el-B., Butler, B., Crocker, P. R., Ackerman, S. J., Valent, P., and Bochner, B. S. (2011). Developmental, malignancyrelated, andcross-species analysis of eosinophil, mast cell, and basophil siglec-8expression. J. Clin. Immunol. 31, 1045-1053.

Inamura, N., Mekori, Y. A., Bhattacharyya, S. P., Bianchine, P. J., and Metcalfe, D. D. (1998). Induction and enhancement of $\mathrm{Fc}($ epsilon)RI-dependent mast cell degranulation following coculture with activated $\mathrm{T}$ cells: dependency on ICAM-1- and leukocyte function-associated antigen (LFA)1-mediated heterotypic aggregation. J. Immunol. 160, 4026-4033.

Irani, A. A., Schechter, N. M., Craig, S. S., Deblois, G., and Schwartz, L. B. (1986). Two types of human mast cells that have distinct neutral protease compositions. Proc. Natl. Acad. Sci. U.S.A. 83, 4464-4468.

Irani, A. M., and Schwartz, L. B. (1994). Human mast cell heterogeneity. Allergy Proc. 15, 303-308.

Jawdat, D. M., Albert, E. J., Rowden, G., Haidl, I. D., and Marshall, J. S. (2004). IgE-mediated mast cell activation induces Langerhans cell migration in vivo. J. Immunol. 173, 5275-5282.

Juremalm, M., and Nilsson, G. (2005). Chemokine receptor expression by mast cells. Chem. Immunol. Allergy 87, 130-144.
Kambayashi, T., Allenspach, E. J., Chang, J. T., Zou, T., Shoag, J. E., Reiner, S. L., Caton, A. J., and Koretzky, G. A. (2009). Inducible MHC class II expression by mast cells supports effector and regulatory $\mathrm{T}$ cell activation. J. Immunol. 182, 4686-4695.

Kashiwakura, J., Yokoi, H., Saito, H., and Okayama, Y. (2004). T cell proliferation by direct cross-talk between OX40 ligand on human mast cells and OX40 on human T cells: comparison of gene expression profiles between human tonsillar and lungcultured mast cells. J. Immunol. 173, 5247-5257.

Kashyap, M., Thornton, A. M., Norton, S. K., Barnstein, B., Macey, M., Brenzovich, J., Shevach, E., Leonard, W. J., and Ryan, J. J. (2008). Cutting edge: CD4 T cell-mast cell interactions alter IgE receptor expression and signaling. J. Immunol. 180, 2039-2043.

Kinet, J. P. (1999). The high-affinity IgE receptor ( $\mathrm{Fc}$ epsilon $\mathrm{RI}$ ): from physiology topathology. Annu. Rev. Immunol. 17, 931-972.

Kitawaki, T., Kadowaki, N., Sugimoto, N., Kambe, N., Hori, T. Miyachi, Y., Nakahata, T., and Uchiyama, T. (2006). IgE-activated mast cells in combination with pro-inflammatory factors induce Th2-promoting dendritic cells. Int. Immunol. 18, 1789-1799.

Leonard, W. J., Ryan, J. J., Kitawaki, T., Kadowaki, N., Sugimoto, N., Kambe, N., Hori, T., Miyachi, Y., Nakahata, T., and Uchiyama, T. (2006). IgEactivated mast cells in combination with pro-inflammatory factors induce Th2-promoting dendritic cells. Int. Immunol. 18, 1789-1799.

Lu, L. F., Lind, E. F., Gondek, D. C., Bennett, K. A., Gleeson, M. W., PinoLagos, K., Scott, Z. A., Coyle, A. J., Reed, J. L., Van Snick, J., Strom, T. B., Zheng, X. X., and Noelle, R. J. (2006). Mast cells are essential intermediaries in regulatory T-cell tolerance. Nature 442, 997-1002.

Malaviya, R., Twesten, N. J., Ross, E. A., Abraham, S. N., and Pfeifer, J. D. (1996). Mast cells process bacterial Ags through a phagocytic route for class I MHC presentation to T cells. J. Immunol. 156, 1490-1496.

Malbec, O., and Daëron, M. (2007). The mast cell IgG receptors, and their roles in tissue inflammation. Immunol. Rev. 217, 206-221.

Malone, D. G., Irani, A. M., Schwartz, L. B., Barrett, K. E., and Metcalfe, D. D. (1986). Mast cell numbers and histamine levels in synovial fluids from patients with diverse arthritides. Arthritis Rheum. 29, 956-963. 
Mantovani, A., Cassatella, M. A., Costantini, C., and Jaillon, S. (2011). Neutrophils in the activation and regulation of innate and adaptive immunity. Nat. Rev. Immunol. 11, 519-531.

Marsh, M. N., and Hinde, J. (1985). Inflammatory component of celiac sprue mucosa. I. Mast cells, basophils, and eosinophils. Gastroenterology 89, 92-101.

Marshal, J. S., Brown, M. G., and Pawankar, R. (2009). "Mast cell and basophils: interaction with IgE, and responses to toll-like receptors activators," in Allergy Frontiers: Classification, and Pathomechanisms, eds R. Pawankar, T. Stephen, S. T. Holgate, and L. J. Rosenwasse (Japan: Springer), 113-129.

Mazzoni, A., Siraganian, R. P., Leifer, C. A., and Segal, D. M. (2006). Dendritic cell modulation by mast cells controls the Th1/Th2 balance in responding T cells. J. Immunol. 177, 3577-3581.

McDermott, J. R., Bartram, R. E., Knight, P. A., Miller, H. R., Garrod, D. R., and Grencis, R. K. (2003). Mast cells disrupt epithelial barrier function during enteric nematode infection. Proc. Natl. Acad. Sci. U.S.A. 100, 7761-7766.

McLachlan, J. B., Hart, J. P., Pizzo, S. V., Shelburne, C. P., Staats, H. F., Gunn, M. D., and Abraham, S. N. (2003). Mast cell-derived tumor necrosis factor induces hypertrophy of draining lymph nodes during infection. Nat. Immunol. 4, 1199-1205.

Mekori, Y. A., and Metcalfe, D. D. (1999). Mast cell-T cell interactions. J. Allergy Clin. Immunol. 104, 517-523.

Merluzzi, S., Frossi, B., Gri, G., Parusso, S., Tripodo, C., and Pucillo, C. (2010). Mast cells enhance proliferation of $\mathrm{B}$ lymphocytes and drive their differentiation toward IgAsecreting plasma cells. Blood 115, 2810-2817.

Metz, M., Grimbaldeston, M. A., Nakae, S., Piliponsky, A. M., Tsai, M., and Galli, S. J. (2007). Mast cells in the promotion and limitation of chronic inflammation. Immunol. Rev. 217, 304-328.

Metz, M., and Maurer, M. (2007). Mast cells - key effector cells in immune responses. Trends Immunol. 28, 234-241.

Minai-Fleminger, Y., Elishmereni, M., Vita, F., Soranzo, M. R., Mankuta, D., Zabucchi, G., and Levi-Schaffer, F. (2010). Ultrastructural evidence for human mast cell-eosinophil interactions in vitro. Cell Tissue Res. 341, 405-415.
Minai-Fleminger, Y., and Levi-Schaffer, F. (2009). Mast cells and eosinophils: the two key effector cells in allergic inflammation. Inflamm. Res. 58, 631-638.

Moon, T. C., St Laurent, C. D., Morris, K. E., Marcet, C., Yoshimura, T., Sekar, Y., and Befus, A. D. (2010). Advances in mast cell biology: new understanding of heterogeneity and function. Mucosal Immunol. 3, 111-128.

Moritz, D. R., Rodewald, H. R., Gheyselinck, J., and Klemenz, R. (1998). The IL-1 receptor-related T1 antigen is expressed on immature and mature mast cells and on fetal blood mast cell progenitors. J. Immunol. 161, 4866-4874.

Nakae, S., Suto, H., Iikura, M., Kakurai, M., Sedgwick, J. D., Tsai, M., and Galli, S. J. (2006). Mast cells enhance $\mathrm{T}$ cell activation: importance of mast cell costimulatory molecules and secreted TNF. J. Immunol. 176 2238-2248.

Nakano, N., Nishiyama, C., Yagita, H., Koyanagi, A., Akiba, H., Chiba, S., Ogawa, H., and Okumura, K. (2009). Notch signaling confers antigenpresenting cell functions on mast cells. J. Allergy Clin. Immunol. 123, 74-81, e1.

Nie, X., Cai, G., Zhang, W., Wang, H., Wu, B., Li, Q., and Shen, Q. (2011). Lipopolysaccharide mediated mast cells induce IL-10 producing regulatory $\mathrm{T}$ Cells through the ICOSL/ICOS axis. Clin. Immunol. 142, 269-279.

Oh, C. K., and Metcalfe, D. D. (1996). Activated lymphocytes induce promoter activity of the TCA3 gene in mast cells following cell-to-cell contact. Biochem. Biophys. Res. Commun. 221, 510-514.

Oldford, S. A., Haidl, I. D., Howatt, M. A., Leiva, C. A., Johnston, B., and Marshall, J. S. (2010). A critical role for mast cells and mast cell-derived IL-6 in TLR2-mediated inhibition of tumor growth. J. Immunol. 185, 7067-7076.

Otsuka, A., Kubo, M., Honda, T., Egawa, G., Nakajima, S., Tanizaki, H., Kim, B., Matsuoka, S., Watanabe, T., Nakae, S., Miyachi, Y., and Kabashima, K. (2011). Requirement of interaction between mast cells and skin dendritic cells to establish contact hypersensitivity. PLoS ONE 6, e25538. doi:10.1371/journal.pone. 0025538

Ott, V. L., Cambier, J. C., Kappler, J., Marrack, P., and Swanson, B. J. (2003). Mast cell-dependent migration of effector CD8+ T cells through production of leukotriene B4. Nat. Immunol. 4, 974-981.
Pawankar, R., Okuda, M., Yssel, H. Okumura, K., and Ra, C. (1997). Nasal mast cells in perennial allergic rhinitics exhibit increased expression of the Fc epsilonRI, CD40L IL-4, and IL-13, and can induce IgE synthesis in B cells. J. Clin. Invest. 99, 1492-1499.

Piazuelo, M. B., Camargo, M. C., Mera, R. M., Delgado, A. G., Peek, R. M. Jr., Correa, H., Schneider, B. G., Sicinschi, L. A., Mora, Y., Bravo, L. E., and Correa, P. (2008). Eosinophils and mast cells in chronic gastritis: possible implications in carcinogenesis. Hum. Pathol. 39, 1360-1369.

Piconese, S., Gri, G., Tripodo, C., Musio, S., Gorzanelli, A., Frossi, B., Pedotti, R., Pucillo, C. E., and Colombo, M. P. (2009). Mast cells counteract regulatory T-cell suppression through interleukin-6 and OX40/OX40L axis toward Th17-cell differentiation. Blood 114, 2639-2648.

Poncet, P., Arock, M., and David, B. (1999). MHC class II-dependent activation of CD4+ T cell hybridomas by human mast cells through superantigen presentation. J. Leukoc. Biol. 66, 105-112.

Ramos, B. F., Qureshi, R., Olsen, K. M., and Jakschik, B. A. (1990). The importance of mast cells for the neutrophil influx in immune complexinduced peritonitis in mice. $J$. Immunol. 145, 1868-1873.

Ramos, B. F., Zhang, Y., Qureshi, R., and Jakschik, B. A. (1991). Mast cells are critical for the production of leukotrienes responsible for neutrophil recruitment in immune complex-induced peritonitis in mice. J. Immunol. 147 1636-1641.

Sander, L. E., Lorentz, A., Sellge, G., Coëffier, M., Neipp, M., Veres, T., Frieling, T., Meier, P. N., Manns, M. P., and Bischoff, S. C. (2006). Selective expression of histamine receptors H1R, H2R, and H4R, but not $\mathrm{H} 3 \mathrm{R}$, in the human intestinal tract. Gut 55, 498-504.

Shefler, I., Salamon, P., Reshef, T., Mor, A., and Mekori, Y. A. (2010). T cell-induced mast cell activation: a role for microparticles released from activated T cells. J. Immunol. 185, 4206-4212.

Shortman, K., and Liu, Y. J. (2002). Mouse and human dendritic cell subtypes. Nat. Rev. Immunol. 2, 151-161.

Sick, E., Niederhoffer, N., Takeda, K., Landry, Y., and Gies, J. P. (2009). Activation of CD47receptors causes histamine secretion from mast cells. Cell. Mol. Life Sci. 66, 1271-1282.
Skokos, D., Botros, H. G., Demeure, C., Morin, J., Peronet, R., Birkenmeier, G., Boudaly, S., and Mecheri, S. (2003). Mast cell-derived exosomes induce phenotypic and functional maturation of dendritic cells and elicit specific immune responses in vivo. J. Immunol. 170, 3037-3045.

Skokos, D., Goubran-Botros, H., Roa, M., and Mecheri, S. (2002). Immunoregulatory properties of mast cell-derived exosomes. Mol. Immunol. 38, 1359-1362.

Smith, T. J., and Weis, J. H. (1996). Mucosal $\mathrm{T}$ cells and mast cells share common adhesion receptors. Immunol. Today 17, 60-63.

St John, A. L., Rathore, A. P., Yap, H., Ng, M. L., Metcalfe, D. D., Vasudevan, S. G., and Abraham, S. N. (2011). Immune surveillance by mast cells during dengue infection promotes natural killer (NK) and NKT-cell recruitment and viral clearance. Proc. Natl. Acad. Sci. U.S.A. 108, 9190-9195.

Stelekati, E., Bahri, R., D’orlando, O., Orinska, Z., Mittrucker, H. W., Langenhaun, R., Glatzel, M., Bollinger, A., Paus, R., and Bulfone-Paus, S. (2009). Mast cell-mediated antigen presentation regulates CD8+ $\mathrm{T}$ cell effector functions. Immunity 31, 665-676.

Stopfer, P., Mannel, D. N., and Hehlgans, T. (2004). Lymphotoxin-beta receptor activation by activated $\mathrm{T}$ cells induces cytokine release from mouse bone marrow-derived mast cells. J. Immunol. 172, 7459-7465.

Suto, H., Nakae, S., Kakurai, M., Sedgwick, J. D., Tsai, M., and Galli, S. J. (2006). Mast cell-associated TNF promotes dendritic cell migration. J. Immunol. 176, 4102-4112.

Svensson, M., Stockinger, B., and Wick, M. J. (1997). Bone marrow-derived dendritic cells canprocess bacteria for MHC-I and MHC-II presentation to $\mathrm{T}$ cells. J. Immunol. 158, 4229-4236.

Tchougounova, E., Pejler, G., and Abrink, M. (2003). The chymase, mouse mast cell protease 4 , constitutes the major chymotrypsin-like activity in peritoneum and ear tissue. A role for mouse mast cell protease 4 in thrombin regulation and fibronectin turnover. J. Exp. Med. 198, 423-431.

Theoharides, T. C., Donelan, J. M., Papadopoulou, N., Cao, J., Kempuraj, D., and Conti, P. (2004). Mast cells as targets of corticotropinreleasing factor and related peptides. Trends Pharmacol. Sci. 25, 563-568.

Tkaczyk, C., Frandji, P., Botros, H. G., Poncet, P., Lapeyre, J., Peronet, R., 
David, B., and Mecheri, S. (1996). Mouse bone marrow-derived mast cells and mast cell lines constitutively produce B cell growth and differentiation activities. J. Immunol. 157, 1720-1728.

Valitutti, S., and Espinosa, E. (2010). Cognate interactions between mast cells and helper T lymphocytes. Self Nonself 1, 114-122.

Vliagoftis, H., and Befus, A. D. (2005). Rapidly changing perspectives about mast cells at mucosal surfaces. Immunol. Rev. 206, 190-203.

Vosskuhl, K., Greten, T. F., Manns, M. P., Korangy, F., and Wedemeyer, J. (2010). Lipopolysaccharidemediated mast cell activation induces IFN-gamma secretion by NK cells. J. Immunol. 185, 119-125.

Waldorf, H. A., Walsh, L. J., Schechter, N. M., and Murphy, G. F. (1991). Early cellular events in evolving cutaneous delayed hypersensitivity in humans. Am. J. Pathol. 138, 477-486.

Wang, Y., and Thorlacius, H. (2005). Mast cell-derived tumour necrosis factor-alpha mediates macrophage inflammatory protein-2-induced recruitment of neutrophils in mice. Br. J. Pharmacol. 145, 1062-1068.

Weller, C. L., Collington, S. J., Brown, J. K., Miller, H. R., Al-Kashi, A., Clark, P., Jose, P. J., Hartnell, A., and Williams, T. J. (2005). Leukotriene $\mathrm{B} 4$, an activation product of mast cells, is a chemoattractant for their progenitors. J. Exp. Med. 201, 1961-1971.

Wershil, B. K., Wang, Z. S., Gordon, J. R., and Galli, S. J. (1991). Recruitment of neutrophils during IgE-dependent cutaneous late phase reactions in the mouse is mast cell-dependent. Partial inhibition of the reaction with antiserum against tumor necrosis factor-alpha. J. Clin. Invest. 87, 446-453.

Williams, C. M., and Galli, S. J. (2000). Mast cells can amplify airway reactivity and features of chronic inflammation in an asthma model in mice. J. Exp. Med. 192, 455-462.

Wong, C. K., Ng, S. S., Lun, S. W., Cao, J., and Lam, C. W. (2009). Signalling mechanisms regulating the activation of human eosinophils by mastcell-derived chymase: implications for mast cell-eosinophil interaction in allergic inflammation. Immunology 126, 579-587.

Yang, Z., Zhang, B., Li, D., Lv, M., Huang, C., Shen, G. X., and Huang, B. (2010). Mast cells mobilize myeloidderived suppressor cells and Treg cells in tumor microenvironment via IL-17 pathway in murine hepatocarcinoma model. PLoS ONE 5, e8922. doi:10.1371/journal.pone.0008922

Zhang, Y., Ramos, B. F., and Jakschik, B. A. (1992). Neutrophil recruitment by tumor necrosis factor from mast cells in immune complex peritonitis. Science 258, 1957-1959.

Zhao, X. J., Mckerr, G., Dong, Z., Higgins, C. A., Carson, J., Yang, Z. Q., and Hannigan, B. M. (2001). Expression of oestrogen and progesterone receptors by mast cells alone, but not lymphocytes, macrophages or other immune cells in human upper airways. Thorax 56, 205-211.
Conflict of Interest Statement: The authors declare that the research was conducted in the absence of any commercial or financial relationships that could be construed as a potential conflict of interest.

Received: 20 March 2012; accepted: 27 April 2012; published online: 25 May 2012.

Citation: Gri G, Frossi B, D'Inca F, Danelli L, Betto E, Mion F, Sibilano $R$ and Pucillo C (2012) Mast cell: an emerging partner in immune interaction. Front. Immun. 3:120. doi: 10.3389/fimmu.2012.00120

This article was submitted to Frontiers in Molecular Innate Immunity, a specialty of Frontiers in Immunology.

Copyright (c) 2012 Gri, Frossi, D'Inca, Danelli, Betto, Mion, Sibilano and Pucillo. This is an open-access article distributed under the terms of the Creative Commons Attribution Non Commercial License, which permits non-commercial use, distribution, and reproduction in other forums, provided the original authors and source are credited. 